\title{
African Countries and International Investment Law: Right to Regulate or Appropriate Regulation or Both?
}

\author{
Emmanuel Laryea \\ Faculty of Law, Monash University \\ Emmanuel.Laryea@monash.edu \\ Oladapo Fabusuy \\ Faculty of Law, Monash University \\ Oladapo.Fabusuy@monash.edu
}

\begin{abstract}
The explosion of Investor-State Dispute Settlement (ISDS) cases from the late 1990s has caused many to criticise the current International Investment Agreements (IIAs) regime. These criticisms include: (1) that the substantive law grants sweeping rights to investors, curtailing the ability of host-state governments to adequately regulate in the public interest; and (2) that the ISDS system enhances corporate power over national sovereignty and interests. While newer IIAs seek to secure for host-states more regulatory space, the measures that often trigger claims by investors have received little attention. This article argues, in the context of African countries, that inappropriate actions of public officials are a major, if not the main, cause of claims against them. If so, a wider regulatory space for host-states, while important, would make little difference to the incidence of ISDS claims against African states. Appropriate regulation is equally, if not more, important.
\end{abstract}

\section{Introduction}

The explosion of Investor-State Arbitration (ISA) cases from the late 1990s has caused many governments, inter-governmental organisations, policy makers, academics, and civil society to rethink International Investment Law, particularly the International Investment Agreements (IIAs), regime (Sornarajah 2015; Garcia et al., 2015; Brower and Schill 2009; 
Pauwelyn 2014; Franck 2009; Salacuse and Sullivan 2005; Caron 2008). ${ }^{1}$ The current regime has been criticised on various grounds. These criticisms can be grouped under two broad aspects, the substantive law and investment dispute resolution mechanism.

Among the criticisms of the substantive law are that many of the IIAs ${ }^{2}$ grant sweeping rights to investors that create an imbalance between investors and host-states. These IIAs, critics argue, curtail the ability of host-state governments to adequately regulate the activities of foreign investors, who are ever ready and willing to commence proceedings against host-states whose regulation diminish the investments and profits of investors.

Criticisms of dispute resolution are mainly against the dominant mechanism for settling investment disputes, Investor-State Dispute Settlement ("ISDS") or, more precisely, Investor-State Arbitration (ISA). ${ }^{3}$

1 For example, South Africa has terminated its International Investment Agreements (IIAs) with Denmark, France, Germany, Netherlands, and the UK. India too terminated all of its IIAs, and has now drafted its new model IIA. Civil Society Organisations calling for reform include the International Institute for Sustainable Development and the Columbia Center on Sustainable Investment

${ }^{2}$ IIAs are treaties between two or more states covering investment relationships between nationals (or other identifiable entities) of one state in the jurisdiction of another. The treaty may be specifically for investments or be contained, usually as a chapter, in a broader International Economic Agreement (IEA) covering not just investment but also trade between the state parties and their nationals. It may be bilateral (i.e. between two states), regional (often between a few countries in a geographical area) or between countries in dispersed regions that share a common goal in investment promotion and regulation. Treaties between two states that are solely on investments are often referred to as Bilateral Investment Treaties (BITs). These dominate the IIA regime. The United Nations Conference on Trade and Development (UNCTAD) estimates the number of BITs at 2,911, of which 2,353 are in force, and some 388 of the other types (i.e. investment chapters in broader International Economic Agreement-Free Trade Agreements or Preferential Trade and Investment Agreements - covering both trade and investment) of which 313 are in force. See https://investmentpolicy.unctad.org/international-investmentagreements (summarising the bilateral investment treaties and treaties with investment provisions as of 12 July 2019).

3 While investment disputes may be resolved by litigation, mediation, conciliation, negotiation or arbitration, parties, particularly investors, often choose arbitration (investor-state arbitration (ISA)) over the other mechanisms. Some investors have even sought to bypass provisions in IIAs that require them to seek resolution by one or more of the other mechanisms before initiating ISA proceedings. See, e.g. Emilio Agustin Maffezini v The Kingdom of Spain (Decision on Jurisdiction) (ICSID Case No ARB/97/7, 25 January 2000), where the claimant, an Argentine national, succeeded in bypassing a requirement in the Argentina-Spain Bilateral Investment Treaty that disputes must first be submitted to the domestic courts of the host state before, if unresolved, they can be 
Criticisms are that ISA enhances the power of multinational corporations at the expense of national sovereignty and interests and allows judicial or government decisions in sovereign states to be challenged before private arbitrators, who might not be trained judges. ISA tribunals are perceived to interpret the laws pro-investor, rather than in a balanced manner, to the disadvantage of sovereign states. It is also said that ISA leads to 'regulatory chill'. That is, with the prospects of claims by investors against the host-state before perceived pro-investor tribunals, host-state governments may refrain from implementing legitimate policies for fear of triggering ISA (United Nations Commission on International Trade Law [UNCITRAL] 2018). ${ }^{4}$ (For a general discussion of the criticisms of ISDS, see French 2015; Dolzer 2014.) These perceived flaws in both the substantive law on international investment and its dispute resolution mechanism are considered to constrain the regulatory space of host-state governments. This has given rise to calls from many for host-states' 'Right to Regulate' (Spears 2010; Kriebaum 2007; Markert 2011).

Much has been done in the last fifteen years to secure to host-states more regulatory space and this can be seen from provisions in newer IIAs. Examples include the introduction of express provisions on the right to regulate, and to ensure that regulations in specific sectors, such as health and environment, do not trigger investor claims (Comprehensive and Progressive Agreement for Trans-Pacific Partnership [CPCTPP] 2018; Australia-United States FTA, 2004; COMESA CIAA 2007). However, what seems to have received less attention is 'appropriate regulation' - that is, the regulatory measures that often trigger claims by investors, and associated criticism of the IIA regime. A government may have the right to regulate, and yet be liable if it regulates inappropriately.

We argue that, while the sweeping investment protection clauses in IIAs signed by states, particularly the first generation, may have impinged on the regulatory space of host-states, and been a cause for investor claims, inappropriate (and avoidable) actions of public officials of African countries are a major, if not the main, cause of claims against them. If so, while it is important that host-states secure for themselves wider regulatory space, as it is being done in the newer IIAs, that would make little difference to the

submitted to an ISA tribunal. For further discussion on why investors prefer ISA, see, Laryea, 2018 and Crawford et al., 2018.

${ }^{4}$ Other criticisms, or concerns about investor-state dispute settlement (ISDS) regard lack of consistency, coherence, predictability and correctness of arbitral decisions by ISDS tribunals; perceived lack of independence and impartiality of tribunal members; and the high cost and duration of cases. 
incidence of ISA claims against African states. Appropriate regulation is equally, if not more, important. This article draws on some cases against African countries to demonstrate this point.

Following this introduction, the first section on The International Investment Law Regime and Its Discontents outlines the IIAs regime and the issues surrounding calls for the right to regulate. The second section ask the question is the Right to regulate problem more apparent than real? This section also discusses efforts underway to reform the IIA regime to secure for states appropriate regulatory space. The third section on African Countries and IIL regime discusses experiences of African economies with the international investment regime. It argues that there are disproportionate claims against African economies relative to their foreign investment inflows and finds that many of the claims have been triggered by inappropriate acts of African governments. This article then concludes with some thoughts on how African economies may avoid claims in the future.

\section{The International Investment Law Regime and Its Discontents}

The body of law now commonly described as international investment law (IIL), or international law of foreign investment, evolved from public international law and has developed quickly in the last three decades. Though the main sources of IIL are rooted in public international law (international treaties, customary international law, general principles of law, judicial or arbitral decisions, and equity), the dominant source is IIAs. These are treaties signed between states, under which the State parties, as potential host and home governments of investments, make explicit commitments to each other towards investors who are nationals of the other State. They involve direct negotiations between the governments, establishing the terms and conditions for private investment by nationals and companies of one country in the jurisdiction of the other. The IIAs seek to afford protections for the investing nationals and entities in the absence of a multilateral investment treaty and in the face of uncertainties regarding protections under customary international law.

While the text of IIAs vary, they typically offer a wider array of substantive protections than are available under customary international law. They usually: (1) require national treatment and most-favoured-nation treatment of foreign investments in the host country; (2) protect contractual rights; (3) guarantee the right to the transfer of profits in hard currency to the home country of investors; (4) prohibit or restrict the use of performance requirements; and (5) provide for international arbitration of disputes 
between the investor and the host-state, typically through the International Centre for Settlement of Investment Disputes (ICSID) or under the arbitration rules of the United Nations Commission on International Trade Law. This way, the investor receives a credible commitment of fair treatment from the potential host government and an assurance that the investor can seek redress in an independent international tribunal not subject to the vagaries of the host government.

As noted, currently there are over 3200 IIAs, comprising 2,911 bilateral investment treaties (BITs) (of which 2,353 are in force), and some 388 investment chapters in broader International Economic Agreements (IEAs) (of which 313 are in force). The IIA regime proliferated in the 1990s, when developing (capital importing) countries began to enter into BITs with developed (capital exporting) countries with the aim of attracting capital flows. While fewer than 400 BITs were concluded between 1959 (when the first of the modern IIAs is said to have been concluded between the then West Germany and Pakistan) and 1989, some 2,000 were signed in the following 15 years. By the end of 2018, the number of BITs was in excess of 2,900 and IEAs incorporating investment provisions numbered over 380 .

The first generation of IIAs tended to grant to foreign investors sweeping protections, far more protections than are available under customary international law. Often, they accorded foreign investors protections and rights far superior to those afforded domestic investors. Many African countries are parties to such IIAs, mostly BITs with developed countries as counter-parties. ${ }^{5}$ Investors enforce those IIAs against African states. ${ }^{6}$

As will be seen below, however, the content of IIAs may not necessarily be the problem. There are instances where investors' claims based on firstgeneration IIAs have failed because the host state's regulations were wellintended, and appropriately formulated and implemented (Glamis Gold v USA; Methanex v USA; Philip Morris v Australia). Where investors' challenges have succeeded, it is often inappropriate domestic regulatory environments, inappropriate acts by public officials, and lopsided investment contracts that are the source of the problem. As illustrated by the cases discussed below, some governments have acted in complete disregard for the contractual rights of investors or respect for due process.

\footnotetext{
${ }^{5}$ Based on UNCTAD's data, about 52 (of the 54) African countries have such IIAs in force. See: https://investmentpolicy.unctad.org/international-investment-agreements/ advanced-search.

${ }^{6}$ According to UNCTAD's data, 18 cases have been enforced against African Host States. See: ibid..
} 
Besides, many ISA cases against African countries are not based on IIAs; they are based on breaches of contract or infringements on obligations under customary international law. For instance, the following four ISA cases against Ghana were not based on IIAs: Biloune v Ghana, Vacuum Salt v Ghana, Balkan Energy v Ghana, and Bankswitch v Ghana. By contrast, the authors are aware of only two cases against Ghana that were based on IIAs, namely Telekom Malaysia $v$ Ghana and Hamester $v$ Ghana.

\section{Right to regulate problem more apparent than real?}

There is plenty in the literature arguing that the first-generation IIAs constrain the regulatory space of host-states. However, the experiences of many developed economies may suggest that the first generation IIAs do not necessarily undermine the right of host-states to regulate, and that they allow for prudent exercise of regulatory powers by host-sates. Brower and Schill (2009, p.484) have argued that even in the absence of textual references, arbitral tribunals recognise the right of states to regulate for legitimate purpose and are not required to compensate foreign investors if governmental regulatory action was bona fide, non-discriminatory, and does not constitute expropriation (i.e. the taking of investors' property). We use two countries, USA and Australia, as examples for the purposes of analysis. Both countries are signatories to several first-generation IIAs. ${ }^{7}$ Both countries are recipients of huge foreign investments. And, although there have been ISA cases against them, neither has lost to an investor, yet.

\section{United States' Experience}

According to the UNCTAD data, the United States has 89 IIAs in force, and its inward FDI stock was US\$7.8 trillion as at 2018 (UNCTAD 2018). The United States has been Respondent in 16 cases instituted under first generation IIAs and has lost none (UNCTAD Data). It won the ten cases that have been decided. Four of the cases were settled, the investor-claimant discontinued one, and one is still listed as pending. The fact that the US won some of these cases is illuminating; they reveal that investors are likely to fail when they challenge well-intended public regulation that is implemented following due process. Two of the cases won by the US are discussed here.

\footnotetext{
${ }^{7}$ Australia has concluded 40 IIAs while US has 114. Source: UNCTAD Investment Policy Hub, https://investmentpolicy.unctad.org/international-investment-agreements/byeconomy.
} 
The Claimant was a Canadian-based manufacturer of methanol, an ingredient used as gasoline additive commonly called MTBE (methyl tertbutyl ether). The State of California banned the use of MTBE as a gasoline additive on the ground that it was contaminating surface water and groundwater in the state. The Claimant challenged the ban, arguing that it constituted a breach of national treatment, fair and equitable treatment and that the measures amounted to expropriation.

The Tribunal held that the legislative process in California leading to the ban had been transparent, subject to due process, and based on scientific report which was subjected to a peer review. Further, the tribunal concluded that the ban was a non-discriminatory regulation for public purpose. As such, it did not constitute an expropriation and was therefore non-compensable.

\section{Two: Glamis Gold v United States of America}

The Claimant, a Canadian mining company engaged in the mining of precious metals, challenged a California regulatory measures requiring backfilling and grading for mining operations near Native American sacred sites. The Claimant contended that these measures were arbitrary and discriminatory, designed to block their project rather than genuinely address environmental and cultural concerns associated with mining activities generally. The Claimant further argued that the cost of complying with the law reduced the value of their investment and, therefore, constituted expropriation. They also argued that the measures were in violation of USA's fair and equitable treatment obligations.

The Tribunal dismissed the claims, deciding in favour of the US Government and the State of California. It ruled that the measures taken by California did not constitute expropriation and held that the measures were not in violation of the fair and equitable treatment standard. According to the tribunal, the measure neither constitute a gross denial of justice nor was it an arbitrary measure or lacking in due process.

\section{Australia's Experience}

Australia has 35 IIAs in force (UNCTAD Data), and has attracted inward FDI stock worth US\$662 billion (UNCTAD, p.188). Australia has been respondent in two cases. The first is the much-discussed Phillip Morris $v$ 
Australia case, which Australia won, and the second case, APR Energy and others v. Australia, seems abandoned.

The decision in the Phillip Morris case demonstrates that investor-state arbitral tribunals are willing to uphold host-state's right to regulate in deserving circumstances, especially in instances of abuse of rights by investors. The dispute in this case arose from the introduction of plain packaging legislation for tobacco products sold in Australia aimed at reducing smoking rates in Australia. The law prohibits use of trademarks, symbols, graphic or images on tobacco products and packaging. The claimant challenged the government's measure before an arbitral tribunal, arguing that it infringed on its intellectual property rights, and sought compensation. The case was not decided on its merits, because the tribunal declined jurisdiction. However, the tribunal, in deciding on the jurisdictional challenge, observed that the claimant was aware that the Australian government would pursue the plain packaging policy when it acquired the subsidiary company.

The tribunal considered the fact that at the material time, $100 \%$ of the shares in Philip Morris Asia were owned by the parent company located in Switzerland, which had no IIA with Australia. Philip Morris International then undertook a restructure in 2011, which meant that Philip Morris Asia, located in Hong Kong, with which Australia has an IIA, became the sole owner of the shares in the Australian subsidiaries. Based on these facts, the tribunal dismissed the claim on the grounds that the commencement of the arbitration by Phillip Morris Asia constituted an abuse of rights. According to the tribunal, the restructuring was for the sole purpose of gaining treaty protection.

The APR Energy v Australia case is still listed as pending but is unlikely to go further. Nothing has happened since the Claimants issued a letter on 30 November 2016 notifying Australia of its intention to commence arbitration, and Australia's response on 11 January 2017 that there is no arbitral jurisdiction under the US-Australia FTA.

\section{$\underline{\text { Right to regulate not necessarily repudiated }}$}

The US and Australia's experiences, and the fact that, overall, host states have won more treaty-based ISA cases than they have lost, ${ }^{8}$ do not necessarily repudiate, or dismiss, the right to regulate concerns. Regulatory

${ }^{8}$ According to UNCTAD, 35\% of the cases have been decided in favour of States, while $22.9 \%$ have been decided in favour of Investors. The remaining percentage have been discontinued, settled or decided in favour of neither party. See $<$ https://investmentpolicyhub.unctad.org/ISDS $>$ accessed 6 March 2019. 
chill may still be happening, and there is empirical evidence for it (Tienhaara 2011, pp.617-618). Gerald Ruggie, the Special-Representative of the United Nations' Secretary-General (SRSG) on the Issue of Human Rights, Transnational Corporations and Other Business Enterprises, also shares the regulatory chill sentiment. According to him,

[r]ecent experience suggests that some [investment] treaty guarantees and contract provisions may unduly constrain the host Government's ability to achieve its legitimate policy objectives, including its international human rights obligations. That is because under threat of binding international arbitration, a foreign investor may be able to insulate its business venture from new laws and regulations, or seek compensation from the Government for the cost of compliance (SRSG Report, 2009).

The experiences of US and Australia may not paint the full picture regarding the experiences of developed countries. Canada has lost four out of 27 cases as respondents, ${ }^{9}$ while Spain has lost six out of 49 cases as respondents. ${ }^{10}$ It is arguable that the experiences of US and Australia may be the result of self-censoring, borne out of a desire to maintain a reputation as a credible host-state because a good reputation as an investment friendly destination is vital in attracting foreign investment. Alternatively, it is arguable that the US and Australia have observed due process, and implemented regulations more appropriately.

\section{Problems with right to regulate are being addressed}

As noted, newer IIAs expressly address the problems, or perceived problems, associated with the right to regulate. This is being done in many ways, including curtailing or narrowing the rights and protections accorded foreign investors, curtailing the ability of investors to treaty-shop, retaining discretions for host-states, and carving out of coverage in IIAs areas of public interest, public health and environmental regulations.

${ }^{9}$ Canada won 8 of these cases, 8 cases were either discontinued or settled and the remaining 7 are pending. Source: <https://investmentpolicy.unctad.org/investmentdispute-settlement/country/35/canada/respondent $>$ accessed 15 July 2019.

${ }^{10}$ Spain has won 3 of these cases, one case was discontinued and the remaining 39 are pending. $\quad$ Source: $\quad<$ https://investmentpolicy.unctad.org/investment-disputesettlement/country/197/spain/respondent $>$ accessed 15 July 2019 


\section{1: Curtailing investor and investment protections and rights}

Host-states are taking measures to curtail investor and investment protections and rights through different means. For instance, India has a new model IIA that does not contain a most-favoured-nation (MFN) clause, ${ }^{11}$ and requires the exhaustion of local remedies before triggering ISA. ${ }^{12}$ Australia and the US did not include an ISA provision in their investment chapter of the 2004 Australia-United States Free Trade Agreement. Australia has also adopted a case-by-case approach in relation to ISA for future IIAs (Morosini and Badin 2017). Thus, ISA is no longer the default rule for Australia, and even when it settles for it, the clauses relating to ISA are extensively negotiated.

General exceptions clauses are now being introduced in IIAs to curtail investors' rights to challenge legitimate regulatory action of the host-states (Henckels 2018). These clauses exempt states from liability for taking certain measures carried out for public interest or public purpose. For example, Article 9.8 of the investment chapter of the 2015 Australia - China FTA provides:

For the purposes of this Chapter and subject to the requirement that such measures are not applied in a manner which would constitute arbitrary or unjustifiable discrimination between investments or between investors, or a disguised restriction on international trade or investment, nothing in this Agreement shall be construed to prevent a Party from adopting or enforcing measures:

(a) necessary to protect human, animal or plant life or health;

(b) necessary to ensure compliance with laws and regulations that are not inconsistent with this Agreement;

(c) imposed for the protection of national treasures of artistic, historic or archaeological value; or

(d) relating to the conservation of living or non-living exhaustible natural resources.

\footnotetext{
${ }^{11}$ See Chapter II of the 2015 Model Text for the Indian Bilateral Investment Treaty (India Model BIT). It omits the most-favoured-nation treatment from the investment protection standards.

122015 India Model BIT, Article 15. Copy available at: (https://investmentpolicy.unctad.org/international-investment-agreements/treatyfiles/3560/download) (accessed 25 July 2019).
} 
Further, some new IIAs seek to give non-investment objectives the same normative footing as investment protection. They do this by incorporating new-fashioned preambles that indicate that the parties to the treaty intend to achieve their investment policy objectives in a manner that is compatible with other policy objectives such as sustainable development. ${ }^{13}$

Preambles form the object and purpose of a treaty and are relevant in interpreting IIA provisions in line with the Vienna convention (VCLT 1969, art. 31(2)). ISA tribunals have used preambles of IIAs to emphasize the investment protection function of IIAs (Siemens v Argentina; Saluka v Czech Republic; BG Group v Argentina). Thus, the location of other noninvestment objectives, such as sustainable development, in the preamble of new IIAs afford tribunals the opportunity to balance investment protection with other objectives and to curb the propensity by investors to challenge every regulatory measure by host states.

\section{2: Curtailing investment treaty and forum shopping}

Treaty shopping refers to the practice of restructuring an investment with the sole purpose of accessing more favourable procedural or substantive investment provisions in IIAs perceived to offer protections that are otherwise not available to the investor (Baumgartner, 2016, p.33). In order to reduce the incidence of treaty shopping, States now incorporate the requirement of substantial business activities into their IIAs in order to prevent so-called 'mailbox' or 'shell companies' established in their territory from benefiting from treaty protection (Colombia-Switzerland BIT 2006; Chile-South Africa BIT 1998).

\section{3: Granting to host-states (IIA parties) discretions to deny investors benefit of IIAs}

States have devised means to address the issue of treaty shopping by investors through what is known as denial of benefits clauses. Those clauses allow host-state that is party to an IIA to deny benefit of the IIA to investors of the other party who may have the form, but not substance, of nationality

\footnotetext{
13 See, e.g., Preamble of the 2016 Morocco - Nigeria BIT, which provides: "SEEKING to promote, encourage and increase investment opportunities that enhance sustainable development within the territories of the state parties... UNDERSTANDING that sustainable development requires the fulfilment of the economic, social and environmental pillars that are embedded within the concept."
} 
of that other party. For instance, the 2015 India Model BIT, art. 35 provides that:

A Party may at any time, including after the institution of arbitration proceedings in accordance with Chapter IV of this Treaty, deny the benefits of this Treaty to:-

an investment or investor owned or controlled, directly or indirectly, by persons of a non-Party or of the Host State; or

ii) an investment or investor that has been established or restructured with the primary purpose of gaining access to the dispute resolution mechanisms provided in this Treaty.

4: Narrowing the propensity for expansive interpretation by arbitral tribunals

New IIAs incorporate interpretive statements that define the scope of investment protection to forestall expansive interpretation by ISA tribunals that potentially constrain host-states from pursuing legitimate policy objectives. For instance, the US Model BIT 2012 states that its provision on expropriation and compensation 'shall' be interpreted in line with its Annex (art. 6(1) and Annex B(4)). The Annex excludes legitimate public welfare objectives, such as public health, safety, and the environment, which are nondiscriminatory, from the scope of indirect expropriation.

The 2014 Canadian Model BIT adopts the same approach (art. 13 and Annex B.13 (1)). The 2007 COMESA Common Investment Area Agreement (CIAA) provides:

Consistent with the right of states to regulate and the customary international law principles on police powers, bona fide regulatory measures taken by a Member State that are designed and applied to protect or enhance legitimate public welfare objectives, such as public health, safety and the environment, shall not constitute an indirect expropriation under this Article. (art. 20(8)) (emphasis added)

These IIA provisions reduce the scope of discretion for arbitral tribunals to engage in broad interpretation that can limit host-states' regulatory space. 
Another example is the 2015 Norway Model BIT, which contains a footnote that limits the possibility of a broad interpretation of the national treatment and most-favoured-nation treatment. It states:

The Parties agree/ are of the understanding that a measure applied by a government in pursuance of legitimate policy objectives of public interest such as the protection of public health, human rights, labour rights, safety and the environment, although having a different effect on an investment or investor of another Party, is not inconsistent with national treatment and most favoured nation treatment when justified by showing that it bears a reasonable relationship to rational policies not motivated by preference of domestic over foreign owned investment (art. 3 and 4).

\section{$\underline{\text { Right to Regulate In IIAs }}$}

There are IIAs that expressly incorporate the right of host-sates to regulate as well as their right to pursue development goals. For instance, Article 20.1 of the Southern African Development Community (SADC) Model BIT recognises the host-state's right to regulate for developmental purposes within its territory consistent with the goals and principles of sustainable development, and with other legitimate social and economic policy objectives. It further allows states the discretion to grant preferential treatment to qualifying enterprises and to impose certain performance requirements (art. 21.2(b)).

\section{African Countries and IIL regime}

Currently, African countries, collectively, have 568 IIAs in force (UNCTAD data). These are in addition to several regional investment instruments (Common Market for Eastern and Southern Africa [COMESA] 2007; SADC Model Bilateral 2012; SADC Protocol on Finance and Investment; Economic Community of West African States [ECOWAS] Supplementary Act) and an investment instrument at the continental levelthe Pan African Investment Code. The total FDI stock for the continent stands at around US \$ 866 billion (UNCTAD 2018, p.188). This is a fraction of what United States alone has attracted, and only about US\$200 billion more than that of Australia. When the populations of the US (327 million), Australia (24 million), and the African continent (1.2 billion) are considered, Africa's 
FDI per capita is minuscule. The statistics suggest that simply signing IIAs is not enough to attract FDI. Building capacity, the presence of solid domestic infrastructure for banking services, capital markets, and domestic policies on good governance and transparency are necessary to attract FDI (Ogutcu 2002).

As discussed below, despite Africa's FDI stock being relatively small, African countries have been respondents to a disproportionate number of ISA claims relative to their FDI stock.

Disproportionate number of cases against African economies relative to FDI inflows

African States have been Respondents in 101 of the 942 known treatybased ISA cases. ${ }^{14}$ Of the 101 cases, 61 have been discontinued, settled, decided in favour of neither party or are pending. The remaining 40 were decided on their merits, with African states winning 27 and losing 13. It would appear that there is no end in sight to this trend. Five out of the 10 most recently concluded ISA cases by ICSID that are publicly available on ICSID's website involved African states as respondents. ${ }^{15}$ Considering that FDI flow to Africa is on the average less than $3.6 \%$ of global FDI flows in the last 15 years, and Africa's FDI Stock is around 2.75\% of Global FDI

\footnotetext{
${ }^{14}$ UNCTAD Policy Hub. The data are based on treaty-based arbitration and do not include non-treaty-based ISA cases. Treaty-based ISA claims are those in which the claims are based on alleged breaches of IIAs. Non-treaty claims are those in which the claims are based on breaches of contract or customary international law, because there is no IIA between claimant's home state and the host state. For instance, according to UNCTAD's data Ghana has been a respondent in only two treaty-based ISA cases. But Ghana has been Respondent in other cases as listed in Part II above, and later discussed in this article.

15 See, ICSID, 'Concluded Cases with Details', at $<$ https://icsid.worldbank.org/en/Pages/cases/ConcludedCases.aspx? status $=\mathrm{c}>\quad$ accessed 19 June 2019. The African States involved are Gabon, Gambia and Egypt. The cases are: Société d'Energie et d'Eau du Gabon and Veolia Africa v. Gabonese Republic and Société de Patrimoine du service public de l'eau potable, de l'énergie électrique et de l'assainissement (ICSID Case No. ARB/18/36), concluded March 29, 2019; Société d'Energie et d'Eau du Gabon v. Gabonese Republic (ICSID Case No. CONC/18/1), concluded September 19, 2018; APCL Gambia B.V. v. Republic of The Gambia (ICSID Case No. ARB/17/40), discontinued June 7, 2018; African Petroleum Gambia Limited and APCL Gambia B.V. v. Republic of The Gambia (ICSID Case No. ARB/17/39), discontinued June 7, 2018; and LP Egypt Holdings I, LLC, Fund III Egypt, LLC and OMLP Egypt Holdings I, LLC v. Arab Republic of Egypt (ICSID Case No. ARB/16/37), discontinued July 11, 2018.
} 
Stock as at the end of $2017,{ }^{16}$ the number of cases against African economies is disproportionately high. ${ }^{17}$

\section{$\underline{\text { Reasons for the disproportionate number of cases }}$}

If, as argued in this article, African countries (and indeed Latin American countries too) have seen a disproportionate number of ISA cases brought against them, then it is important to examine the causes. As noted, many attribute these cases to IIAs, which are perceived to grant expansive rights to investors, and restrain government's regulatory space. However, we argue that it is more than that. There are other factors. One is that African countries may be targeted for claims by investors because they are perceived to have economic and governance weakness. Another factor is bad, lopsided, contractual terms concluded by African countries. Yet another, is inappropriate actions of public authorities. We examine the part that these elements, including IIAs, may have played.

\section{1: IIAs as cause of high number of cases}

African countries are parties to a significant number of first-generation IIAs. These IIAs contain traditional investment protections such as fair and equitable treatment, guarantee against expropriation, most-favoured-nation and national treatment. Further, these IIAs contain dispute resolution clauses that confer jurisdiction on an international arbitral tribunal. They confer on investors right of access in order to institute claims before arbitral tribunals against host-states' actions that conflict with these investment protection obligations. This right of access granted to investors, typically corporations, to seek redress at international forum may be a cause of the proliferation ISA cases against states on the continent. (Mohamadieh and Uribe 2016;

\footnotetext{
16 Percentage calculated using UNCTAD's World Investment Report 2018, 188. The global FDI stock is USD $\$ 31,525,356$ (million dollars) while Africa's total stock is USD $\$ 866,817$ (million dollars).

${ }^{17}$ It must be noted that there have been a high number of ISA cases against some nonAfrican economies too, such as Argentina (60), Spain (49) and Venezuela (47). Depending on how these are considered, they have either made the figures for Africa more respectable or, if one considers them as anomalies to be disregarded, then Africa's situation is worse. A majority of the cases against Argentina were based on the measures taken by Argentina during its financial crises in 2001. The economic nationalisation agenda pursued by Hugo Chávez is the reason for the high number of cases against Venezuela. The reduction in the incentives for investments in the production of electricity from renewable energy triggered the cases against Spain.
} 
Bungenberg et al., 2015; Ostrove et al., 2018). In other words, some of the cases may not have been initiated if there were no IIAs in place. The reason is that customary international law, which the claimants would have had to rely on, does not afford them the rights they have sought to enforce.

\section{2: African States are targets for ISA cases}

It has been argued that the availability of third-party funding in investment arbitration is another reason for the increased investment arbitration against African states (Garcia 2018, p.2913). According to Garcia (2018, p.2914), third-party funding is a 'specialized form of dispute financing in which a third-party finances the costs of arbitral proceedings for a party in a dispute that is subject to arbitration under a treaty-based ISDS provision'. It allows investors to out-source the financial cost associated with initiating investment arbitration. With the financial cost of ISA proceedings transferred to the Third-party Funder, there is incentive for investors to continue to bring investment claims. Investment arbitration are particularly lucrative for third-party funders because the amount of compensation resulting from such claims far exceeds the compensation awarded in commercial arbitration (Garcia, 2018, p.2915). The aim of third-party funders, like most investment vehicles, is to look for avenues that provide maximum returns on investment. In achieving this, third-party funders specifically target weaker Host States that do not have adequate resources and capacity for a robust legal defence at investment arbitration (Garcia 2018, p.2917). The lack of adequate legal defence increases the chances of the host-state losing at ISA.

Similarly, some investors may have initiated treaty-based claims in circumstances they would not have tested if the host-state were a developed country. In Hamester $v$ Ghana, the Claimant, a German company, that concluded a joint venture agreement (JV) with a Ghanaian state-owned corporation, was itself allegedly in breach of the agreement. However, the Claimant alleged breaches on the part of the Ghanaian state-owned corporation, and instituted an ISA proceeding relying on the Germany-Ghana BIT. The tribunal ruled that none of the acts of the corporation complained of was attributable to Ghanaian government, because the corporation is not an organ of the Ghanaian state but a commercial company created by statute (para 188). Further, the tribunal ruled that there was no evidence that the corporation acted on the instructions or direction of the Ghanaian state, and that the acts of the corporation complained of by the claimant were purely commercial (para 199-200, 329). More importantly for our purpose, the 
tribunal ruled that acts attributable to Ghana did not amount to breach of the BIT (para 362 (iv)). This was a pure contractual claim, and the umbrella clause in Article 9(2) of the BIT does not automatically transform all contractual claims into treaty claims. It is arguable that this was a weak and misguided claim that would not have formed the basis of an ISDS claim if the respondent (Ghana) was a developed, well-resourced, country.

\section{3: Lopsided Investment Contract Terms}

In addition to IIA protections, many investors, particularly those engaging in natural resource extraction, the building of public infrastructure or provision of public utilities, often enter into investment contracts with hoststates. These contracts take different forms including Concession contracts, joint-venture agreements, production-sharing contracts, and risks service contract (Looper et al., 2012). Such contracts signed between African countries and investors are often imbalanced, granting investors extremely generous returns to the disadvantage of the host state.

For instance, in the midst of high commodity prices and international competition for resources in the mid-2000s, Liberia granted concessions on lopsided fiscal and other terms over iron ore and rubber in 2005 (Kaul et al., 2009). It was so bad that the successor government was able, with the support of Liberia's donor partners and civil society, to renegotiate two of the major concessions, yielding several improvements to the country's take from the exploited resources (Kaul, 2009). Factors contributing to such lopsided contracts, and their concomitant disadvantages to African states, include lack of capacity and incompetence of government negotiators, lack of transparency, neglect of duty, and corruption on the part of public officials (Laryea 2011). Sometimes, after a bad deal has been signed by one government, a succeeding government may try to renegotiate the terms to rectify the imbalance (as Liberia did in the example above) or abrogate the contract altogether. Without the cooperation of the investor, an attempt to renegotiate is likely to lead to investor-claims in arbitration, as does abrogation.

Further, African states sometimes agree to stabilization clauses in their contracts with investors. The Amoco v Iran tribunal defined a stabilization clause as the "contract language which freezes the provisions of a national system of law chosen as the law of the contract as to the date of the contract in order to prevent the application to the contract of any future alterations of the system'. Such clauses prevent host-states from altering the status quo (legal, administrative or otherwise) in existence at the time of executing the 
contract. Put differently, these clauses preclude host-states from regulatory actions that potentially impact the particular investments. The broadest form of stabilization clauses is found in the African extractive industries (Shemberg, 2009). These are a source of investors' claims against African states, such that the negative experiences of African states under investment arbitration have informed the jurisprudence on stabilization clauses (AGIP v Congo; Liberian Eastern Timber Corporation v. Liberia; Texaco Overseas Petroleum Co. v. Libya).

\section{4: Inappropriate Regulation}

There are merits in the reasons adduced above as contributing factors to the disproportionate number of cases against African countries. However, it is the contention of the present authors that inappropriate regulation is the main cause. Inappropriate regulation exacerbates each of the points discussed above. Inappropriate regulation should be understood broadly, to include abrogation of contracts or concessions, unprincipled revocation or nonrenewal of licenses, arbitrariness, and lack of due process. Effective or appropriate regulation would do the opposite-respect contractual rights, eschew unprincipled and arbitrary acts, and promote observance of due process. Appropriate regulation would reduce the risk and incidence of ISDS cases against African countries. We discussed in above how Australia and the United States have been respondents to smaller numbers of ISA cases relative to their FDI inflow and FDI Stock. Not only that, neither country has as yet lost an ISA case.

African states may have the right to regulate, but that will not reduce the number of investor-claims against them if they do not change their attitude, to adopt appropriate regulation methods in their dealings with foreign investors. By way of example, we discuss some ISA cases in which African states engaged in inappropriate regulation, and damages were awarded against them.

\section{a: Siag v Egypt}

The Claimants in this case, both natural citizens of Italy, were the principal investors in two Egyptian corporations, Touristic Investments and Hotels Management Company (SIAG) S.A.E. and Siag Taba Company. In 1989, the Egyptian Ministry of Tourism sold a large parcel of oceanfront land on the Red Sea's Gulf of Aqaba to SIAG to develop a tourist resort. SIAG subsequently transferred a portion of the property to Siag Taba Company. 
While construction was ongoing at the project site, Egypt's minister of tourism issued a ministerial resolution that purportedly cancelled the project and sought to reclaim the land and structures on the site. Afterwards, Mr Siag, one of the claimants, was detained for deciding to challenge the ministerial resolution, but was later released. The police forcefully took over the site despite orders of the Egyptian Courts (up to the highest courts) declaring that the actions of the government were unlawful and invalid, and also granting declaratory and injunctive relief orders in favour of the Claimant. In an attempt to give the expropriation a veneer of legitimacy, the Prime Minister issued a decree purportedly expropriating the Claimant's assets for public purpose, which the Egyptian courts declared as unlawful. This led to the Claimant submitting claim under the Italy-Egypt BIT. Unsurprisingly, the Tribunal ruled that Egypt was liable for unlawful expropriation of the claimant's investment and had breached the fair and equitable treatment obligation. In the words of the tribunal, the actions of Egypt constituted an 'egregious denial of justice to Claimants' (para 455).

\section{b: Biwater Gauff Limited v Tanzania}

In 2003, Tanzania secured a joint World Bank, African Development Bank and European Investment Bank funding for USD 140,000,000 for commissioning a comprehensive program of repairs and upgrades to, and the expansion of, the Dar es Salaam Water and Sewage Infrastructure (the "Project"). As a condition of the funding, Tanzania was required to appoint a private operator to manage and operate the water and sewage system, and to carry out some of the works associated with the Project. The Claimant secured the bid and thereafter established a local company with local participation as required under Tanzanian law. Consequently, the Tanzanian public corporation assigned the operation of the water and the sewage system to the newly formed company by way of a lease contract. Subsequently, the Minister of Water and Livestock department terminated the Claimant's contract, deported the claimant's management staff, and the government took over the Claimant's business. The Claimant successfully challenged these measures based on the protection standards contained in the UK-Tanzania BIT such as guarantee expropriation, fair and equitable treatment, obligation to grant full protection and security to investors. 


\section{c: Biloune v Ghana}

Mr Antoine Biloune and Marine Drive Complex Ltd (MDCL) (a Ghanaian corporation in which Biloune was the principal shareholder) was initially granted a lease in November 1985 by the Ghana Tourist Development Company (GTDC) (a state-owned corporation formed by the Ghanaian Government to operate tourist facilities) to renovate and manage a restaurant at the Marine Drive Complex in Accra, Ghana. In 1986 MDCL entered into a joint venture agreement with GTDC for the construction and management of 4-star hotel resort complex. GTDC contributed the land, for a share of $51 \%$ stake in the venture, and MDCL was to finance and manage the construction and operation of the hotel, for a share of $49 \%$ in the venture. MDCL applied to the Ghana Investment Centre (GIC), another state agency, and was given approval for the investment. About a year into the construction, the local government in the area where the land was located, the Accra City Council, served a notice on the parties to the venture to stop work, and to 'show cause' why the construction should not be demolished. Before the expiration of the notice period, to 'show cause', Biloune and other officers of MDCL were asked to report to the National Investigations Committee (NIC). NIC officers asked Biloune to declare his assets, giving him a form to complete for that purpose. Subsequently, NIC referred Biloune to the Office of Revenue Commission. After Mr. Biloune or his accountants requested and obtained a number of extensions to the deadline to file his assets declaration form, he was arrested and held in custody for thirteen days without charge. He was then deported from the country, on the grounds that his presence in Ghana was "not conductive to the public good", and warned never to return to the country.

Biloune initiated an arbitral claim against the GIC and the government of Ghana. This was not under an IIA, as Syria, Biloune's state of nationality, had no IIA with Ghana. Biloune's case was based on Ghana's breaches of contract and of customary international law. The Tribunal found that "the conjunction of the stop work order, the demolition, the summons, the arrest, the detention, the requirement of filing assets declaration forms, and the deportation of Mr. Biloune without possibility of re-entry" (para 26) had the effect of constructively expropriating MDCL's assets, and Mr. Biloune's investment (para 30). It concluded that the Government of Ghana was liable under and international law, and was ordered to pay compensation to $\mathrm{Mr}$. Biloune.

Even if Biloune infringed any laws of Ghana (and Ghana adduced very little evidence to that effect), the Ghanaian authorities seem to have abused 
their authority in their treatment of him, and thereby breached international law. Appropriate regulation required them to accord him due process, the right and time to be able to defend whatever allegations the government had against him, without harassment. The methods adopted by the Ghanaian authorities were totally wrong in any civilised system, and would not escape liability however wide the government's right to regulate is conceived.

\section{d: Process and Industrial (P\&ID) v Federal Republic of Nigeria}

A UK engineering firm, P\&ID, entered into a Gas Supply and Processing agreement with the ministry of petroleum resources in 2010. Based on the agreement, P\&ID was to build facilities to refine wet gas to be used in generating electricity. Nigeria, on its part, was to construct pipeline for the project and also supply P\&ID with fixed quantities of wet gas over a 20 -year period.

The total cost incurred on the project by P\&ID was about US $\$ 40$ million but the facilities were never constructed and no wet gas was ever delivered. The failure of Nigeria to meet its obligations three years after the agreement was concluded was treated as a repudiation of the agreement. P\&ID thereafter invoked the arbitration clause in the agreement, claiming damages from the Nigerian government to cover the twenty years profits they would have made on the project. In January 2017, the tribunal awarded the P\&ID a sum of US $\$ 6.59$ billion (being the value of income for the 20 -year project) against Nigeria in addition to $7 \%$ per year in interest on the sum, which elevated the award to about US\$9 billion. In March 2017, P\&ID filed a petition before the US court to confirm the award. Nigeria failed to participate in the proceedings and a default judgement was entered against Nigeria. The award has also been confirmed by the UK Commercial Court, for enforcement against Nigeria's assets in the jurisdiction. There are similar enforcement proceedings in the United States District Court for the District of Columbia too to enforce the award against Nigerian assets in the USA.

The facts of this case demonstrate the disregard some African governments have for contractual obligations. For three years, the Nigerian government failed to perform its obligations. Furthermore, Nigeria failed to participate in the proceedings for no good reason, which resulted in default judgment against the country. This award, if it is eventually enforced, would deplete Nigeria's public resources, leaving serious adverse consequences for the nation and its citizens. The amount of the award is extraordinary, the second largest in ISA history, for sunk cost lost by P\&ID. But the merits of the award is not the subject of discussion here. What we wish to point out 
here is the inappropriateness of the actions of the Nigerian government that led to the arbitral claim in the first place.

\section{e: Telekom Malaysia v Ghana}

In an agreement with the Ghanaian government, Telecom obtained a shareholding in Ghana Telecom, and a management contract to run the company for certain duration. The government decided not to renew the management contract and, instead, put it out to tender. Telekom commenced arbitration proceedings. The case was settled, with Ghana government agreeing to pay an undisclosed amount over two years and to buy-back Telekom's stake in Ghana Telecom.

\section{f: Bankswitch v Ghana}

Bankswitch Ghana Limited, an IT firm, had a contract with the Ghanaian government to provide Ghana Customs with a secure document management system, an internet portal, for the operation of custom clearance at Ghanaian ports. Subsequently, the contract was cancelled, and the Claimant commenced arbitral proceedings. The tribunal ruled that Ghana was liable and ordered payment of compensation to the Claimant.

The foregoing cases illustrate a lack of prudent exercise of regulatory powers. Actions such as the abrogation of contracts by government, disregard for, and destruction of, property rights, lack of due process, needless deployment of security forces and other state agents to harass and intimidate investors, would not pass the test of 'regulation' in any civilised system. Whatever 'right to regulate' and state secures for itself, and however wide the regulatory space is afforded states, many of the actions of African governments seen in the above cases will trigger liabilities.

\section{Conclusion}

African states have faced a high number of ISA cases brought against them by foreign investors, especially so when the share of FDI is taken into consideration. While investment protection clauses in IIAs signed by African states, particularly those of the first-generation, may be a cause for investor claims, inappropriate (and avoidable) actions of public officials of African countries are a major, if not the main, cause of the high number of claims. This is particularly so when one considers that many of the ISA cases against African economies are not based on IIAs, but rather breaches of contract and customary international law. Consequently, carving out wider regulatory 
space in IIAs for African countries hosting or seeking to host foreign investments would make little or no difference to the incidence of ISA cases against them, if they do not change their attitude and treatment of foreign investments. Appropriate regulation is equally, if not more, important in stemming the high number of ISA cases against African economies. In advancing these arguments, reference has been made to the facts of some ISA cases against African countries for illustration.

Inappropriate regulation hinders FDI in at least two ways. First, it raises the transaction cost or cost of doing business, and creates perceptions of unfavourable investment climate, thereby discouraging FDI inflows. Second, it leads to costly ISA cases against African economies; costly to defend and, when it goes in favour of the investor-claimant, costly awards that deplete already scarce state funds needed for public and social goods such as health, education and infrastructure.

\section{References}

Baumgartner, J. (2016). Treaty Shopping in International Investment Law. Oxford: University Press 2016.

Brower, C.N., \& Schill, S.W. (2009). Is Arbitration a Threat or a Boon to the Legitimacy of International Investment Law? Chicago Journal of International Law, 9, 471-498.

Bungenberg, M., Griebel, J., Hobe, S., \& Reinisch, A. (2015). Introduction. In M. Bungenberg, M., Griebel, S. Hobe, \& A. Reinisch (Eds.), International Investment Law. Oxford: Hart.

Caron, D. (2008-9). Investor State Arbitration: Strategic and Tactical Perspectives on Legitimacy. Suffolk Transnational Law Review 32 (2), 513.

Columbia Center on Sustainable Investment. (2017).

http://ccsi.columbia.edu/files/2017/03/CCSI-EU-Court-publicconsultation-submission-15-Mar-17-FINAL.pdf

Crawford, L., Emerton, P., \& Laryea, E. (2018). Investor-State Dispute Settlement and the Australian Constitutional Framework. In C. Picker, H. Wang, \& W. Zhuo (Eds.), The China-Australia Free Trade Agreement: $21^{\text {st }}$ Century Model. London: Hart Publishing.

Dolzer, R. (2014). Perspectives for Investment Arbitration: Consistency as a Policy Goal?. Transnational Dispute Management, 11, 403-410.

Franck, S.D. (2009). Development and Outcomes of Investment Treaty Arbitration. Harvard International Law Journal, 50(2), 435-489.

French, R. (2015). ISDS: Litigating the Judiciary. Public Law Review, 26(3), 155-165. 
Garcia F.J., Ciko, L., Gaurav, A., \& Hough, K. (2015). Reforming the International Investment Regime: Lessons from International Trade Law. Journal of International Economic Law, 18(4), 861-892.

Garcia, F.J. (2018). Third-Party Funding as Exploitation of the Investment Treaty System. Boston College Law Review, 59. 2911-2934.

Henckels, C. (2018). Should Investment Treaties Contain Public Exceptions?. Boston College Law Review, 59, 2825-2844.

International Institute for Sustainable Development https://www.iisd.org/topic/investment-law-and-policy-reform

Kriebaum, U. (2007). Regulatory Takings: Balancing the Interests of the Investor and the State. Journal of World Investment and Trade, 8, 717744.

Laryea, E. (2011). Promoting good governance through ICT systems: improving transparency and reducing corruption. In R.P. Buckley (Ed.), Debt-for-Development Exchanges: History and New Applications (pp.277-279). New York, NY: Cambridge University Press.

Laryea, E. (2018). Making Investment Arbitration Work for All: Addressing the Deficits in Access to Remedy for Wronged Host State Citizens Through Investment Arbitration. Boston College Law Review, 59, 2845-2875.

Markert, L. (2011). The Crucial Question of Future Investment Treaties: Balancing Investor's Rights and Regulatory Interests of Host States. In M. Bungenberg, J. Griebel, \& S. Hindelang (Eds.), International Investment Law and EU Law. Hiedelberg: Springer.

Mohamadieh, K., \& Uribe, D. (2016). The Rise of Investor-State Dispute Settlement in the Extractive Sectors: Challenges and Considerations for African Countries. South Centre Research Paper, 65, 1-28.

Morosini, F., \& Sanchez Badin, M.R. (2017). An Introduction. In F. Morosini \& M.R. Sanchez Badin (Eds.), Reconceptualizing International Investment Law from the Global South Cambridge: Cambridge University Press.

Ogutcu, M. (2002). New Horizons for International Investment and Sustainable Development. The Journal of World Investment, 3, 455471.

Ostrove, M., Sanderson, B., \& Veronelli, A.L. (2018). Developments in African Arbitration. The Middle Eastern and African Arbitration Review 22-29. 
Pauwelyn, J. (2014). At the Edge of Chaos? Foreign Investment Law as a Complex Adaptive System, How It Emerged and How It Can Be Reformed. ICSID Review, 29 (2), 372-418.

Raja Kaul, Antoine Heuty And Alvin Norman, Getting A Better Deal from the Extractive Sector: Concession Negotiation In Liberia 2006-2008 (2009).

http://www.revenuewatch.org/news/public ations/getting-a-better-deal.php

Report of the SRSG, Business and Human Rights: Towards Operationalizing the 'Protect, Respect and Remedy' Framework, A/HRC/11/13, para 30 (2009).

Salacuse, J.W., \& Sullivan, N.P. (2005). Do BITs Really Work?: An Evaluation of Bilateral Investment Treaties and Their Grand Bargain. Harvard International Law Journal, 46(1), 67-130.

Shemberg, A. (2009). Stabilization Clauses and Human Rights (Geneva: United Nations Office of the United Nations High Commissioner for Human Rights) Annex 2, 4.

Sornarajah, M. (2015). Resistance and Change in the International Law on Foreign Investment. Cambridge: Cambridge University Press.

Spears, S.A. (2010). The Quest for Policy Space in a new generation of International Investment Agreements. Journal of International Economic Law, 13(4), 1037-1075.

Talus, K., Looper, S., \& Otillar, S. (2012). Lex Petrolea and the internationalization of petroleum agreements: Focus on Host Government Contracts. Journal of World Energy Law and Business, 5(3), 181-193.

Tienhaara, K. (2011). Regulatory Chill and the threat of Arbitration: A view from political science. In C. Brown \& K. Miles (Eds.), Evolution in Investment Treaty Arbitration. Cambridge; New York: Cambridge University Press.

United Nations Commission on International Trade Law. (2018). 'Possible Reform of Investor-State Dispute Settlement (ISDS)' (Draft) A/CN.9/WG.III/WP.149 $(5$ September), http://www.uncitral.org/pdf/english/workinggroups/wg 3/WGIII36th-session/149 main paper 7 September DRAFT.pdf

United Nations Conference on Trade and Development data: https://investmentpolicyhub.unctad.org/IIA/CountryBits/195\#iiaInne rMenu.

United Nations Conference on Trade and Development. (2018). World Investment Report 2018: Investment and New Industrial Policies. 


\section{Treaties}

1998 Agreement between the Republic of Chile and the Republic of South Africa for the Promotion and Protection of Investments. https://investmentpolicy.unctad.org/international-investmentagreements/treaty-files/706/download.

2004 Australia-United States Free Trade Agreement, https://fat.gov.au/about-us/publications/trade-investment/ australia-united-states-free-trade-agreement-guide-to-theagreement/Pages/ausfta-guide.aspx.

2006 Agreement between the Republic of Colombia and the Swiss Federation on the Promotion and Reciprocal Protection of Investments. $\quad$ https://investmentpolicy.unctad.org/internationalinvestment-agreements/treaty-files/803/download.

2015 Free Trade Agreement between the Government of Australia and the Government of the People's Republic of China. https://investmentpolicy.unctad.org/international-investmentagreements/treaty-files/3453/download.

ASEAN Comprehensive Investment Agreement, (2009), http://inve stasean.asean.org/files/upload/Doc\%2005\%20-\%20ACIA.pdf.

Canada Model BIT: Agreement Between Canada and [Country] for the Promotion and Protection of Investments, Article 13 and Annex B.13(1) (2004). https://investmentpolicy.unctad.org/internationalinvestment-agreements/treaty-files/2820/download.

Common Market for Eastern and Southern Africa. (2007). Common Investment Area Agreement (COMESA CIAA), Article 20(8).

Comprehensive and Progressive Agreement for Trans-Pacific Partnership 2018 , https://www.mfat.govt.nz/assets/CPTPP/Com prehensive-and-Progressive-Agreement-for-Trans-Pacific-Part nership-CPTPP-English.pdf

Economic Community of West African States. Supplementary Act A/SA.3/12/03 adopting Community Rules on Investment and the Modalities for their Implementation.

India Model BIT: Chapter II of the 2015 Model Text for the Indian Bilateral Investment Treaty. https://investmentpolicy.unctad.org /international-investment-agreements/treaty-files/3560/download.

Italy-Egypt BIT: Agreement for the promotion and protection of Investments between the Republic of Italy and the Arab Republic of Egypt, 1989.

Norway Model BIT (draft) 2015: Agreement between the Kingdom of Norway and [Country] for the Promotion and Protection of 
Investments,), Article 3 and 4. https://investmentpolicy.unctad.org international-investment-agreements/treaty-files/3350/download.

Southern African Development Community. (2006). Protocol on Finance and Investment.

Southern African Development Community. (2012). Model Bilateral Investment Treaty, art.21.2(b) https://investmentpolicy.unctad.org /international-investment-agreements/treaty-files/2875/download

UK-Tanzania BIT: Agreement between the Government of the United Kingdom of Great Britain and Northern Ireland and the Government of the United Republic of Tanzania, 1994.

US Model BIT: Treaty Between the Government of the United States of American and the Government of [Country] Concerning the Reciprocal Protection of Investment. https://investmentpolicy.unctad.org/international-investmentagreements/treaty-files/2870/download

VCLT: Vienna Convention on the Law of Treaties 1969.

Cases

African Petroleum Gambia Limited and APCL Gambia B.V. v. Republic of The Gambia (ICSID Case No. ARB/17/39), discontinued June 7, 2018.

AGIP v Congo, Award, 30 November 1979, 1 ICSID Reports 309.

Amoco International Finance v Iran, 15 Iran-US CTR 189, 239 (1987).

LP Egypt Holdings I, LLC, Fund III Egypt, LLC and OMLP Egypt Holdings

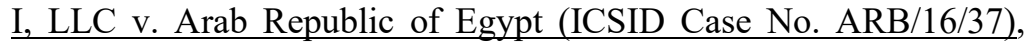
discontinued July 11, 2018.

APCL Gambia B.V. v. Republic of The Gambia (ICSID Case No. $\underline{\mathrm{ARB} / 17 / 40)}$.

APR Energy LLC, Power Rental Asset Co Two LLC, Power Rental Op Co Australia LLC v. Australia, UNCITRAL

Balkan Energy (Ghana) Ltd v The Republic of Ghana, PCA, UNCITRAL Rules, Award on Merits, 1 April 2014.

Bankswitch Ghana Ltd (Ghana) v The Republic of Ghana PCA 118294, UNCITRAL Award Save as to Costs, 11 April 2014.

BG Group v Argentina, Final Award, 24 December 2007.

Biloune and Marine Drive Complex Ltd v. Ghana Investments Centre and the Government of Ghana, 95 I.L.R. 184. (Permanent Court of Arbitration 1990).

Biwater Gauff (Tanzania) Ltd. v. United Republic of Tanzania, ICSID Case No. ARB/05/22. 
Glamis Gold, Ltd. v. The United States of America, UNCITRAL, Award 8 June 2009; Methanex Corp. v. United States of America (2005) 44 ILM 1345;

Gustav F W Hamester GmbH \&amp; Co KG v. Republic of Ghana, ICSID Case No. ARB/07/24.

Liberian Eastern Timber Corporation v. Republic of Liberia, ICSID Case No. ARB/83/2; Texaco Overseas Petroleum Co. v. Libya 17 I.L.M. 1 (1978).

Methanex Corp. v. United States of America (2005) 44 ILM 1345.

Philip Morris Asia Limited v. The Commonwealth of Australia, UNCITRAL, PCA Case No. 2012-12.

Saluka v Czech Republic, Partial Award, 17 March 2006.

Siemens v Argentina, Decision on Jurisdiction, 21 October 2005.

Société d'Energie et d'Eau du Gabon and Veolia Africa v. Gabonese Republic and Société de Patrimoine du service public de l'eau potable, de l'énergie électrique et de l'assainissement (ICSID Case No. ARB/18/36), concluded March 29, 2019; Société d'Energie et d'Eau du Gabon v. Gabonese Republic (ICSID Case No. CONC/18/1), concluded September 19, 2018.

Telekom Malaysia Berhad v. The Republic of Ghana (PCA Case No. HA/RK 2004).

Vacuum Salt Products Limited v Ghana, ICSID Award (1994).

Waguih Elie George Siag and Clorinda Vecchi v. Arab Republic of Egypt (ICSID Case No. ARB/05/15). 